\title{
Political Accountability and Regulatory Performance in Infrastructure Industries: An Empirical Analysis
}

\author{
Farid Gasmi, Paul Noumba Um, and Laura Recuero Virto
}

\begin{abstract}
The relationship between the quality of political institutions and the performance of regulation has recently assumed greater prominence in the policy debate on the effectiveness of infrastructure industry reforms. Taking the view that political accountability is a key factor linking political and regulatory structures and processes, this article empirically investigates its impact on the performance of regulation in telecommunications in time-series-cross-sectional data sets for 29 developing countries and 23 developed countries during 1985-99. In addition to confirming some well-documented results on the positive role of regulatory governance in infrastructure industries, the article provides empirical evidence on the impact of the quality of political institutions and their modes of functioning on regulatory performance. The analysis finds that the impact of political accountability on the performance of regulation is stronger in developing countries. An important policy implication is that future reforms in these countries should give due attention to the development of politically accountable systems. JEL codes: L51, H11, L96, L97, C23
\end{abstract}

Farid Gasmi is a professor at the Toulouse School of Economics, Atelier de Recherche Quantitative Appliquée au Développement Economique (ARQADE) and Institut d'Economie Industrielle (IDEI); his email address is gasmi@cict.fr. Paul Noumba Um (corresponding author) is a lead economist in the Sustainable Development Department of the Middle East and North Africa Region at the World Bank; his email address is pnoumbaum@worldbank.org. Laura Recuero Virto is an economist at the Organisation for Economic Co-operation and Development (OECD); her email address is laura .recuerovirto@oecd.org. An earlier version of this article was presented at the European Network for Training in Economic Research (ENTER) Jamboree, University of Mannheim, 2007; the Research Team on Markets, Employment, and Simulation (ERMES) seminar of the Université Panthéon-Assas Paris II, Paris, 2007; the European Conference on Competition and Regulation, Corfu, 2007; the conference of the European Association for Research in Industrial Economics, Valencia, 2007; the Télécom ParisTech conference on Telecommunications Infrastructure and Economic Performance, Paris, 2008; and the conference on Infrastructure Regulation, What Works, Why, and How Do We Know? Hong Kong, 2009. The authors thank the participants at these events for comments. They are grateful to Jean-Paul Azam, Aida Caldera, Antonio Estache, Frannie Léautier, Wilfried Sand-Zantman, the editor of the journal, and three anonymous referees for useful suggestions. They also thank Luis Hernando Gutierrez, Randeep Rathindran, and Lixin Colin $\mathrm{Xu}$ for help in constructing the data. Part of this research was undertaken during the summer of 2006 while Farid Gasmi and Laura Recuero Virto were visiting researchers at the World Bank Institute. These authors thank the members of the institute, in particular, Gabriela Chenet-Smith, for their warm hospitality.

THE WORLD BANK ECONOMIC REVIEW, VOL. 23, NO. 3, pp. 509-531

doi:10.1093/wber/lhp010

Advance Access Publication October 26, 2009

(C) The Author 2009. Published by Oxford University Press on behalf of the International Bank for Reconstruction and Development / THE WORLD BANK. All rights reserved. For permissions, please e-mail: journals.permissions@oxfordjournals.org 
The last two decades have witnessed a worldwide wave of economic reforms affecting the market structure and the institutions in infrastructure industries, including high-technolgy sectors such as telecommunications and electricity and more traditional domains such as water and postal services. In developed countries, reforms have sought to improve the functioning of industries traditionally organized as-what has come to be recognized as-ill-performing monopolies. The policy task has been to redesign the legal and regulatory frameworks to produce "proper" economic incentives, to induce operators to enhance their offerings, in particular, their cost efficiency, service quality, and tariffs.

While the reforms in developing countries have been grounded on similar principles, in practice they have differed markedly in at least two respects. First, even though there was clearly room for improving the performance of infrastructure industries in developed countries, service was typically available in those countries, whereas it was absent in many parts of developing countries.

Second, and more important, the task of institutional design was far more challenging in developing countries. Developed countries needed to modernize an existing fabric of institutions with a complex system of operating rules built over a long history of political and economic administration of market economies. In most cases, although for different reasons, such crucial experience was lacking in developing countries. Beyond having to establish new institutions to regulate the reformed industries, a challenge in itself due to the scarcity of human capital, developing countries had to deal with inefficient administrative rules.

Following liberalization and privatization of some segments of infrastructure industries and the creation of regulatory authorities, developing countries had to devote considerable effort to improve the efficiency of the new regulatory authorities, by ensuring regulatory independence, adequate human resources capacity, and sound regulatory governance. Meanwhile, theoretical work on designing optimal regulatory institutions and empirical work on measuring their performance suggest that these three policy goals must be considered in the context of governance of the economy as a whole. This article investigates the relative weight of these sector-specific and economywide determinants of regulatory performance in the telecommunications sector, using econometric analysis of separate data sets for developing and developed countries. ${ }^{1}$

The determinants of regulatory performance have been discussed in both the theoretical and the empirical streams of the literature on infrastructure industry

1. This article considers the cellular and the fixed-line telecommunications segments and analyzes the developing and developed country data sets separately. These two segments were chosen because they have typically required regulatory intervention, often in controlling retail and wholesale prices or setting service targets. Developing and developed countries are analyzed separately because the potential gains in estimate efficiency associated with larger data sample size were considered less important than the potential inconsistency in estimates associated with greater data heterogeneity. To avoid adding econometric complexity, the fact that the data from developed and developing countries are not always directly comparable is dealt with in the discussion of the final results. 
regulation. For this analysis, two approaches are distinguished. A first approach, conceptual in nature and inspired by political science, argues that it is political governance that is the relevant determinant of regulatory performance (Spiller and Tommasi 2003). Another, more empirical approach emphasizes the impact of regulatory governance on performance (Cubbin and Stern 2005b). The analysis in this article views the relationship between political and regulatory structures and processes as critical in assessing regulatory performance. It seeks to merge both approaches, inserting some empirical elements into the debate on the relationship between political and regulatory institutions that has so far taken place mainly at a conceptual level.

To do this, a series of econometric significance tests are run, with special attention to variables that capture the degrees of political accountability in the economy. How politically accountable an economic system is depends on how well implemented is the "pro-active process by which public officials inform about and justify their plans of action, their behavior and results, and are sanctioned accordingly" (Ackerman 2005, p. 6). The analysis considers political accountability to be fundamental to the link between political structures and regulatory processes and hence views its (political-game) equilibrium level as an important determinant of the performance of regulatory processes. With that in mind, a testing procedure is established for the hypothesis that, all things being equal, more political accountability should enhance the performance of regulation. In addition to testing the significance of political accountability, the analysis gives some empirical substance to the conjecture that the effect of political accountability is even stronger in developing countries. ${ }^{2}$

The article is organized as follows. Section I summarizes some of the recent theoretical and empirical arguments on the design of institutions and on the evaluation of regulatory performance in infrastructure industries. Not meant to be exhaustive, this section argues the need to merge these two streams of the literature on regulatory institutions. Section II describes the data and some of their general properties. Section III presents the empirical analysis of the relationship between political accountability and regulatory performance. The article concludes with some policy implications of the empirical findings. The appendix contains some summary statistics on the data.

\section{Design of Institutions and Regulatory Performance: The Need for an Integrated Empirical Approach}

Recent contributions to the theory of the design of institutions and empirical work on measurement of their performance have exposed the issue of the

2. From a normative perspective, with better regulatory performance expected to improve social welfare, this suggests that the marginal social benefit of political accountability is higher in developing countries. 
evaluation of regulatory performance. Laffont (2005) meditates on the design of regulatory institutions in developing countries.

Two approaches have been used to examine the determinants of regulatory performance and outcomes. One approach is conceptual and analyzes the role of political structures and processes. Another approach, more empirical, emphasizes the impact of the quality of regulatory governance. This section briefly reviews the main arguments of these two approaches and highlights the need to develop a unified analytical framework. The rest of the article is an empirical effort in that direction.

The theoretical approach analyzes the relationship between political structures and processes and regulation by emphasizing the need to open the black box of the organization and functioning of governments (Estache and Martimort1999; North 2000). ${ }^{3}$ In an analysis of the link between politics and regulation in the United States, McCubbins, Noll, and Weingast (1987) argue that by reducing the costs of monitoring and by sharpening sanctions, administrative procedures can give rise to an equilibrium in which compliance with the preferences of political agents is greater than it otherwise would be. ${ }^{4}$ This relationship is further explored in the telecommunications sector by Levy and Spiller (1994), through case study analysis. In particular, they evaluate the potential for political agents to manipulate the regulatory process. They find that sector performance can be satisfactory under a wide range of regulatory procedures as long as arbitrary administrative decisions can be restrained.

The link between the political and regulatory spheres is further analyzed in Spiller and Tommasi (2003), through the impact that political environments have on the ability of political agents to achieve cooperation over time. They argue that long-term political cooperation is likely to lead to stable and flexible regulatory policies and thus to effective regulation. This is especially the case when the agents with decision power have strong intertemporal relationships, policy and political moves are widely observable, good enforcement technologies are available, and the short-run payoffs from noncooperation are not high. They argue that less efficient regulatory rules resulting from a rigid regulatory context may provide incentives for investment, whereas regulatory discretion may lead to arbitrary outcomes if institutional endowments are low.

Heller and McCubbins (1996) argue that incentives for investing in infrastructure industries are not credible within a given regulatory structure without a political context that makes them sustainable. Regulatory predictability is crucial to credibility, and political institutions play an important role in

3. By emphasizing the political game, this approach fits within the new institutional economics paradigm, which is grounded in the precepts of transaction cost theory and positive political economy. This paradigm constitutes an important departure from the standard normative approach to public economics.

4. Bottom-up "fire-alarm" monitoring through external agents affected by regulatory policies is a good example of a method that can reduce the information costs of monitoring the activities of agencies (McCubbins and Schwartz 1984). 
enhancing this predictability. The higher the quality of the political and institutional environment, the harder it is to change regulatory structures and procedures. In particular, the greater the number of political players with effective authority and veto power, the easier it is to block policy change. The main argument of this line of policy research is that the more established the political structures and processes, the higher the cost of institutional change and the more efficient the conduct of regulation.

The fundamental belief motivating much of the empirical approach that emphasizes the role of regulatory governance in infrastructure industries is that good regulatory governance is a prerequisite to the proper functioning of the positive relationship between regulatory incentives and regulatory performance. This belief is based on the conjecture that "regulatory agencies with better governance should make fewer mistakes, have their mistakes identified and rectified better and more quickly, so that good regulatory practice is more readily established and maintained" (Cubbin and Stern 2005a, p. 3).

The basic empirical implications of these hypotheses is that the structure and practice of regulation thereby entailed—an independent regulator making transparent regulatory decisions-mean that better regulatory governance increases supply capacity and enhances productive and allocative efficiency. In telecommunications, these implications are typically tested with data collected for a set of developing countries observed during a given period. Regulatory performance is measured by mainline coverage rates or mainlines per employee, and regulatory governance is captured by an index that aggregates a set of aspects related to the structure and internal organization of regulation (Gutierrez 2003b). ${ }^{5}$ Overall, when applied to telecommunications (Gutierrez 2003a) and electricity (Cubbin and Stern 2005a), the methodology yields a positive impact of regulatory governance on such regulatory output measures. For a survey of empirical studies on regulatory governance and performance in developing countries, see Cubbin and Stern (2005b).

A typical contribution to this line of research starts with the global conceptual view that "institutional quality is the dominant determinant of variations in long-term growth performance" (Cubbin and Stern 2005a, p. 2; Rodrik, Subramanian, and Trebbi 2004). However, the research often accounts only for the micro dimensions of institutional quality embodied in what is referred to as the "quality" of regulatory governance. This approach could gain substantially in richness by drawing lessons from the literature on the design of institutions, discussed earlier in this section. The analysis here takes a step toward a unified approach that explicitly incorporates variables linking political and regulatory structures and processes when evaluating regulatory

5. These studies and this one use outcome variables to measure regulatory performance. A more rigorous assessment of regulatory performance entails conducting surveys to capture the quality of regulators' decisions that ultimately affects sector outcomes (see Correa and others 2008; Brown and others 2006). Such surveys do not exist but would, if undertaken, provide a better indication of the performance of regulation in infrastructure industries. 
performance, in addition to specifying variables of regulatory governance. The impact of political accountability is captured through variables accounting for macro dimensions of institutional quality that are seen as affecting the level of political accountability in the economic system.

The approach taken here rests on the belief that limiting the use-and sanctioning the abuse-of political power should help in disentangling regulatory processes from the opportunistic behavior of political agents. ${ }^{6}$ The election mechanism should, in principle, ensure political accountability since citizens select the representatives who hold bureaucrats and members of the judiciary system accountable for their behavior. However, this property of elections is hard to satisfy since the electoral process suffers from important information asymmetries between elected politicians and citizens and from lack of accountability of politicians for their past actions. Privatization of government monopolies, liberalization of markets, and the application of private management principles to state-owned entreprises have been demonstrated to improve political agents' accountability much more directly. However, while it is important to consider such pro-accountability reforms, the independence of the regulator, and other factors related to the sector's regulatory governance when analyzing regulatory performance, it is also important to consider other pro-accountability factors related to governance of the economy as a whole-as in the empirical analysis that follows.

\section{The Data}

The data set on developing countries includes Argentina, Bolivia, Brazil, Chile, Colombia, Costa Rica, Côte d'Ivoire, Dominican Republic, Ecuador, El Salvador, Ghana, Guatemala, Honduras, India, Jamaica, Jordan, Kenya, Malawi, Malaysia, Morocco, Pakistan, Panama, Peru, South Africa, Sri Lanka, Tanzania, Thailand, Uganda, and Venezuela. The data set on developed countries includes Australia, Austria, Belgium, Canada, Denmark, Finland, France, Germany, Greece, Iceland, Ireland, Italy, Japan, Luxembourg, Netherlands, New Zealand, Norway, Portugal, Spain, Sweden, Switzerland, the United Kingdom, and the United States. For each country, data were collected on variables regrouped into four categories: regulatory performance, local accountability, global accountability, and other variables (table 1). (For detailed definitions of these variables and their data sources, see Gasmi, Noumba, and Recuero Virto 2006.)

As indicated, regulatory performance is measured by the level of output (mainline coverage or cellular subscriptions), efficiency (mainlines per employee), or price (fixed-line residential service, cellular service). ${ }^{7}$ To match

6. As Spiller and Tommasi (2003) note, opportunistic behavior by politicians can be expected in infrastructure industries because the economic stakes are large.

7. These outcome variables are indirect measures of regulatory performance based on objective data on regulated firms rather than on direct measures based on subjective data reported by surveyed regulatory agencies. 
Table 1. Variables and Their Designation

\begin{tabular}{ll}
\hline Variable & \\
\hline Regulatory performance & \multicolumn{1}{c}{ Designation } \\
$m l$ & Mainline coverage \\
$c e l$ & Cellular subscription \\
eff & Mainlines per employee \\
p_res & Price of monthly subscription to fixed-line service \\
p_cel & Price of cellular service \\
Local accountability & \\
reg & Regulatory governance index \\
Global accountability & \\
corruption & Corruption \\
bureau & Bureaucracy \\
law & Law and order \\
expropri & Expropriation \\
currency & Currency risk \\
institutional & Institutional environment index \\
checks & Checks and balances \\
Other variables & \\
priva & Privatization \\
comp_cix & Competition in fixed line \\
rural & Competition in cellular \\
density & Rural population \\
\hline
\end{tabular}

Note: For defintions of variables, see Gasmi, Noumba, and Recuero Verto (2006).

Source: Authors' analysis based on data described in text.

the conceptual framework discussed in the previous section, variables were regrouped into local and global accountability categories, representing the quality of regulatory governance in the sector and political governance at the economywide level. Therefore, local accountability is captured in variables reflecting the regulator's political and financial independence, the transparency of accounts and regulatory decisions, the clarity of the allocation of responsibilities across institutions, the nature of the legal environment, and the degree of social participation in regulatory decisions. ${ }^{8}$ Global accountability is captured in variables reflecting the quality of the institutional framework (government integrity, efficiency of bureaucracy, strength of courts and enforcement

8. The study thus contributes to the literature on the impact of infrastructure industry reforms by extending the set of variables capturing regulatory governance. In that respect, it stands with Gutierrez (2003a), who has constructed detailed indices of regulator characteristics for the telecommunications sector in Latin American countries, and Holder and Stern (1999), who have done the same for the electricity sector in Asian countries. Estache and Martimort (1999) emphasize the importance of these dimensions to the sustainability of regulatory agencies. In the samples for this study, the regulator became independent at some point during the period under study in 26 of the 29 developing countries and 21 of the 23 developed countries. 
capacity, government commitment capacity, and currency risk) and the quality of the political process (strength of checks and balances). ${ }^{9}$

The variables in the group of other variables control for some effects deemed important when estimating the relationship between political accountability and regulatory performance. Because the telecommunications sector has undergone considerable market structure changes during the period under study, some reform variables are included to reflect these changes, such as privatization of the incumbent and the introduction of competition in fixed and cellular service, as liberalization of these segments has arguably had different market implications (Gasmi and Recuero Virto forthcoming). In the data set on developing countries, 18 of 29 countries partially privatized their telecommnications operator, 14 introduced competition in the local fixed-line segment, and 24 introduced competition in the cellular segment. In the data set on developed countries, 20 of 23 countries partially privatized their telecommnications operator, 10 introduced competition in the local fixed-line segment, and 15 introduced competition in the cellular segment. In both groups, the reforms have coincided with the introduction of new technologies that have substantially reduced costs and increased demand. This group of other control variables thus includes some country-specific demand features that provide information on population density and distribution (urban or rural).

Correlation coefficients between the variables of political accountability and those of regulatory performance show that the correlation is generally stronger for developing countries than for developed countries (table 2). (The appendix provides some summary statistics on the data for developing and developed countries.) Correlation is particularly strong when regulatory performance is measured by mainline coverage, cellular subscription, and mainlines per employee and when political accountability is captured by the strength of checks and balances. The same is true when regulatory performance is measured by mainlines per employee and political accountability by the regulatory governance index, when regulatory performance is measured by cellular subscription or price of cellular service, and when political accountability is captured by the quality of the institutional environment. In both samples, the regulatory performance variables tend to be correlated relatively more strongly with the variables that reflect the quality of the broad institutional environment than with those that reflect the quality of regulatory governance in the sector.

It is instructive to examine the evolution of these variables over the sample period (tables S1 and S2 in the supplemental appendix). When measured by mainline coverage, cellular subscription, or mainlines per employee, regulatory performance has increased twice as much on average in developing countries as

9. Both the empirical and the theoretical literature suggest that it is less the extent of democracy that is relevant to investors and more the ability of the government to credibly commit to a policy regime. The level of policy stability is captured here through an index indicating whether there are an "effective" number of checks and balances. 
TAв в E 2. Correlation Coefficients for Developing and Developed Countries

\begin{tabular}{|c|c|c|c|c|c|c|c|c|c|c|}
\hline \multirow[b]{3}{*}{ Political accountability } & \multicolumn{10}{|c|}{ Regulatory performance } \\
\hline & \multicolumn{2}{|c|}{$\mathrm{ml}$} & \multicolumn{2}{|c|}{ cel } & \multicolumn{2}{|c|}{ eff } & \multicolumn{2}{|c|}{ p_res } & \multicolumn{2}{|c|}{ p_cel } \\
\hline & $\begin{array}{l}\text { Developing } \\
\text { countries }\end{array}$ & $\begin{array}{l}\text { Developed } \\
\text { countries }\end{array}$ & $\begin{array}{l}\text { Developing } \\
\text { countries }\end{array}$ & $\begin{array}{l}\text { Developed } \\
\text { countries }\end{array}$ & $\begin{array}{l}\text { Developing } \\
\text { countries }\end{array}$ & $\begin{array}{l}\text { Developed } \\
\text { countries }\end{array}$ & $\begin{array}{l}\text { Developing } \\
\text { countries }\end{array}$ & $\begin{array}{l}\text { Developed } \\
\text { countries }\end{array}$ & $\begin{array}{l}\text { Developing } \\
\text { countries }\end{array}$ & $\begin{array}{l}\text { Developed } \\
\text { countries }\end{array}$ \\
\hline $\begin{array}{l}\text { Global accountability } \\
\text { institutional }\end{array}$ & & & 0.65 & 0.24 & 0.42 & 0.2 & 0.23 & 0.28 & & \\
\hline $\begin{array}{l}\text { Local accountability } \\
\text { reg }\end{array}$ & 0.19 & 0.43 & 0.57 & 0.55 & 0.30 & 0.05 & -0.06 & 0.01 & 0.61 & -0.07 \\
\hline
\end{tabular}

Source: Authors' analysis based on data described in text and in Gasmi, Noumba, and Recuero Virto (2006). 
in developed countries, most likely reflecting the much higher level of unmet demand in developing countries in the early part of the study period. In contrast, when measured by the price of monthly subscription to fixed-line service, which has increased in both developing and developed countries, or the price of cellular service, which has decreased, regulatory performance has improved more noticeably in developed countries. This conclusion should be moderated, however. The significantly greater increase in the price of monthly subscription to fixed-line service in developing countries might be due to the more intense tariff rebalancing in these countries. Furthermore, the significantly lower decline in the price of cellular service in developing countries might reflect a relatively less mature segment of the market-and hence with less effective competition-than in developed countries.

This brief review of the data also reveals greater improvement in the quality of the institutional environment and the political process in developing countries than in developed countries during the period under study. However, again, caution is required in interpreting this observation as it might reflect only the fact that these countries lagged considerably behind on these two dimensions.

\section{IiI. Empirical Analysis of the Relationship between Political Accountability and Regulatory Performance}

This section briefly reviews the methodology, summarizes some results on data stationarity and Granger causality, and discusses the results of the regressions of regulatory performance and measures of political accountability. (For more details on the methodology, see Gasmi, Noumba, and Recuero Virto 2006.)

\section{Econometric Methodology}

As the data sets include time-series and cross-sectional data, differenced generalized method of moments (DIF-GMM) was used for estimating. Preliminary statistical tests supported the presence of dynamic and fixed effects and suggested the use of this method, developed by Arellano and Bond (1991) for analyzing panel data and applied by Beck and Katz (2004) to time-series and cross-sectional data.

A typical relationship is specified as a dynamic equation given by

$$
\log \left(y_{i t}\right)=\alpha_{0}+\alpha_{1} \log \left(y_{i t-1}\right)+\mathbf{x}_{i t}^{\prime} \beta+\mu_{i}+\varepsilon_{i t},
$$

where $i=1,2, \ldots, N ; t=1,2, \ldots, T ; y_{i t}$ is a one-dimensional dependent variable representing regulatory performance; $\alpha_{0}$ and $\alpha_{1}$ are scalar parameters; $\mathbf{x}_{i t}$ is a vector of regressors representing, among other things, political accountability, in country $i$ at time $t ; \beta$ is the associated vector of parameters; $\mu_{i}$ captures a country-specific fixed effect; and $\varepsilon_{i t}$ is a disturbance term. For both data sets, 
$T=15$. For the developing country data set, $N=29$, and for the developed country data set, $N=23$. Standard assumptions $E\left(\mu_{i}\right)=0, E\left(\varepsilon_{i t}\right)=0$, $E\left(\varepsilon_{i t} \mu_{i}\right)=0$, and $E\left(y_{i 1} \varepsilon_{i t}\right)=0$ are made on the fixed-effect and disturbance terms.

In this setting, estimation can potentially be plagued by endogeneity coming from a correlation between the regressors and the fixed-effect term and a correlation between the regressors and the disturbance term. ${ }^{10}$ The endogeneity problem stemming from the correlation of the first type is taken care of by expressing equation (1) in first differences. However, this transformation brings with it another endogeneity problem due to the contemporaneous correlation between $\log \left(y_{i t-1}\right)$ and the error term $\varepsilon_{i t-1}$. This correlation is of the same nature as the correlation of the second type. Thus, the endogeneity problem basically comes down to finding instruments to use in estimating this equation in first differences. The standard approach, followed here, is to select instruments from lagged values of the potentially endogenous regressors.

Before estimating the equation, the technical issue of stationarity of the dependent variable must be addressed because lack of stationarity can have two undesirable consequences in this context. One is that any estimation method applied to a nonstationary dynamic system is likely to yield inaccurate estimates. Another consequence, related to the application of DIF-GMM, is that the available instruments for the equation in first differences are likely to be weak, which would impoverish the finite-sample properties of the estimator. A method suggested by Blundell and Bond $(1998,1999)$ is used to address stationarity (see also Arellano and Bover 1995).

As indicated, this investigation of the effect of political accountability relies on a set of regressions. While estimation of the coefficients enables assessment of the (quantitative) impact of the political accountability variables on the regulatory performance variables, first asking whether there is a causal relationship between these variables permits meaningful interpretation of this impact. For this purpose, the DIF-GMM estimation technique is combined with a Granger-causality testing procedure developed by Holtz-Eakin, Newey, and

10. In this context, a correlation might be expected between the extent of reforms, captured by some regressors, and some country characteristics, such as country size and wealth, which are embodied in the fixed-effect term. Moreover, the regressors used to capture the degree of privatization and competition are likely to be endogenous, especially in the early stages of reform (Ros 1999). For example, licenses are typically granted conditional on the fulfillment of specified performance targets based on coverage, quality, or some other dimensions of the industry and are often associated with exclusivity periods. Endogeneity might also be a concern when using variables to capture some aspects of the structure of regulatory institutions. An example is the variable on the existence of an independent regulator, since the decision to create an independent regulator and its timing can be influenced by pre-regulatory performance. For an empirical account of the endogeneity of regulatory policies, see Gasmi and Recuero Virto (forthcoming), Gutierrez (2003b), and Ros (2003), among others. 
Rosen (1988) for panel data. The following equation is estimated:

$$
\Delta \log \left(y_{i t}\right)=\sum_{k=1}^{m} \alpha_{k} \Delta \log \left(y_{i t-k}\right)+\sum_{k=1}^{m} \delta_{k} \Delta x_{i t-k}+\Delta \mathbf{x}_{i t}^{\prime} \beta+\Delta \varepsilon_{i t}
$$

where $\Delta$ is the first difference operator. This equation tests whether a variable used to capture political accountability, $x$, Granger-causes the variable to measure regulatory performance $y$.

\section{Results}

On stationarity, tables S3 (for developing countries) and S4 (for developed countries) in the supplemental appendix show the results of the estimation of a first-order autoregressive process, AR(1), with both the DIF-GMM and system (SYS)-GMM methods applied to the variables in levels and a time trend. The tables also show the results for the DIF-GMM method applied to the variables that capture regulatory performance in first differences where they are found to be nonstationary in levels. The tables give the DIF-GMM and SYS-GMM (one-step robust) estimates of the $\mathrm{AR}(1)$ coefficient; the estimate of the time trend coefficient, Time; the first- and $n$ th-order autocorrelation coefficients of the residuals in first differences, $m 1$ and $m n$, respectively; the value of the $J$-statistic for testing the validity of the instruments; the value of the Dif-Sargan statistic for testing the validity of the additional SYS-GMM conditions; the value of the starting lag of the instruments, $L$; and the number of observations. Based on the analysis of the results, the series in first differences was used for both the developing and developed countries data sets (see Gasmi, Noumba, and Recuero Virto 2006 for details).

On the existence of causal relationships, tables S5-S10 show the DIF-GMM estimation results on which the testing procedures are built, asking whether the variables of local accountability (the regulatory governance index reg) and global accountability (the institutional environment index, institutional; and the index of checks and balances, checks) Granger-cause the variables of regulatory performance (mainline coverage, $\mathrm{ml}$; cellular subscription, $\mathrm{cel}$; mainlines per employee, eff; price of monthly subscription to fixed-line service, p_res; and price of cellular service, $\left.p_{-} c e l\right) .{ }^{11}$ In addition to showing the estimated values of the parameters associated with the explanatory variables, tables S5S10 include three Wald statistics. Goodness of fit tests the joint significance of the coefficients associated with the explanatory variables. Lag length tests the joint significance of the coefficients associated with the dependent variable and the political accountability variable with the greatest lag length. Causality tests the joint significance of the coefficients associated with the lagged political accountability variables when the lag length test accepts the significance of the

11. Some additional control variables are also included, as needed, and account for any possible endogeneity problem. The estimates shown in these tables are those of the parameters of equation (2). 
TABLE 3. Granger-causality relationships for developing and developed countries

\begin{tabular}{|c|c|c|c|c|c|c|}
\hline \multirow[b]{3}{*}{ Variable } & \multirow{2}{*}{\multicolumn{2}{|c|}{$\begin{array}{c}\text { Local accountability } \\
\text { reg }\end{array}$}} & \multicolumn{4}{|c|}{ Global accountability } \\
\hline & & & \multicolumn{2}{|c|}{ institutional } & \multicolumn{2}{|c|}{ checks } \\
\hline & $\begin{array}{c}\text { Developing } \\
\text { countries }\end{array}$ & $\begin{array}{c}\text { Developed } \\
\text { countries }\end{array}$ & $\begin{array}{c}\text { Developing } \\
\text { countries }\end{array}$ & $\begin{array}{c}\text { Developed } \\
\text { countries }\end{array}$ & $\begin{array}{c}\text { Developing } \\
\text { countries }\end{array}$ & $\begin{array}{l}\text { Developec } \\
\text { countries }\end{array}$ \\
\hline$m l$ & Yes & No & Yes & Yes & Yes & No \\
\hline cel & No & Yes & Yes & Yes & Yes & Yes \\
\hline eff & No & No & Yes & No & No & No \\
\hline p_res & Yes & Yes & Yes & Yes & Yes & No \\
\hline p_res & Yes & No & Yes & No & No & No \\
\hline
\end{tabular}

Note: Yes indicates evidence of a causal relationship running from the accountability variable to the regulatory performance variable; No indicates no evidence of a causal relationship.

Source: Authors' analysis based on data described in text and in Gasmi, Noumba, and Recuero Virto (2006).

coefficients. The results reported in these tables inform the choice of valid instruments.

For developing countries, the results in all estimations indicate the existence of an acceptable lag length. The Granger-causality test shows that causality runs from regulatory governance to regulatory performance, except when cellular subscription or mainlines per employee variables are used to measure regulatory performance (see table S5). The institutional environment has a causal effect on regulatory performance independently of which of the five variables is used to measure regulatory performance (see table S6). Finally, the political process has a causal effect on regulatory performance except when performance is measured by the variable mainlines per employee or price of cellular service (see table S7).

While some causal relationships are also found in the data on developed countries, the empirical evidence is somewhat weaker (tables S8-S10). In some estimations there is no lag length that is statistically significant and thus no Granger-causality relationship is accepted. For example, when mainline coverage or price of cellular service is used to test whether regulatory governance has a causal relationship with regulatory performance, no lag length is accepted (see table S8). Similarly, the estimations for developed countries do not show causal relationships between the institutional environment and regulatory performance when performance is measured by mainlines per employee or price of cellular service (see table S9) or between the political process and regulatory performance when performance is measured by price of cellular service (see table S10). In cases where a certain lag length is accepted, Granger-causality tests show that regulatory governance is causally related to regulatory performance when performance is measured by cellular subscription or price of monthly subscription to fixed-line service (see table S8) and that institutional 
environment is causally related to regulatory performance when performace is measured by mainline coverage, cellular subscription, or the price of monthly subscription to fixed-line service (see table S9). Finally, the political process is causally related to regulatory performance only when performance is measured by cellular subscription.

Table 3 summarizes the findings on the existence of causal relationships in the two data sets. Overall, the results support the proposition of a causal relationship between political accountability and regulatory performance in both developing and developed countries. This is especially so when political accountability is examined through the quality of the institutional environment. The causal relationships with regulatory performance are stronger for the global accountability variables than for the local accountability variables, especially in developing countries. Even though the empirical evidence of such relationships is stronger for developing countries, the policy implications of the issue warrant careful analysis of the quantitative aspects of these relationships.

The analyses conducted thus far set the ground for closer inspection of the relationship between political accountability and regulatory performance in the two data sets. The Granger-causality tests provided both empirical evidence on the causal relationships and information on the dynamic structure of the relationships and resulted in a list of potential variables for use as regressors when estimating the quantitative impact of political accountability on regulatory performance. To minimize the risk of estimation inaccuracy, a serious concern in dynamic data analysis, the variables used to measure regulatory performance were transformed to make them stationary when needed.

Tables 4 and 5 report DIF-GMM regressions in which some of the main political accountability regressors are drawn from the set of variables that passed the Granger-causality test. The tables, similar to tables S5-S10 of the supplemental appendix, contain three additional items. First, they include two country-specific variables, population density (density) and extent of rural population (rural). Second, they indicate whether the regressors' privatization (priva), competition in fixed line (comp_fix), competition in cellular (comp_cel), and regulatory governance index (reg) were found to be endogenous. Valid instruments are chosen according to the procedure described above. ${ }^{12}$ Third, they give the value of a Wald statistic for testing the joint significance of time-specific effects captured in time dummy variables.

For developing countries, at least one variable for political accountability significantly affects each of the five variables for regulatory performance (see table 4). Except when regulatory performance is measured by the price of monthly subscription to fixed-line service, the sign of the impact is as expected-the greater the political accountability, the better the regulatory

12. In the estimations reported in these tables, the disturbance term in levels does not exhibit any serial correlation except for the series with mainline coverage, where it follows an $\mathrm{MA}(3)$, and the series for mainline per employee and cellular subscription, where it follows an MA(1). 
Taвle 4. Differenced generalized method-of-moments parameter estimates, developing countries

\begin{tabular}{|c|c|c|c|c|c|c|}
\hline$y_{\text {it }}$ & $\mathrm{ml}_{\mathrm{it}}$ & $\mathrm{cel}_{\mathrm{it}}$ & $\mathrm{eff}_{\mathrm{it}}$ & $y_{\text {it }}$ & p_res ${ }_{i t}$ & p_cel ${ }_{\text {it }}$ \\
\hline$y_{i t-1}$ & $0.248 *$ & $0.329 * *$ & $-0.136^{*}$ & $y_{i t-1}$ & $-0.241 * *$ & $-0.221 * * *$ \\
\hline $\operatorname{reg}_{i t-1}$ & $0.003 * *$ & & & $\operatorname{reg}_{i t-1}$ & $-0.010 *$ & \\
\hline corruption $_{i t-1}$ & & $0.080 * * *$ & 0.007 & $\operatorname{reg}_{i t-2}$ & & $-0.008 * *$ \\
\hline burean $_{i t-1}$ & & -0.010 & 0.021 & corruption $_{i t-1}$ & -0.003 & 0.030 \\
\hline$l a w_{i t-1}$ & & 0.017 & $0.019 *$ & bureau $_{i t-1}$ & 0.001 & 0.040 \\
\hline expropri $i_{i t-1}$ & & 0.002 & -0.001 & $\operatorname{law}_{i t-1}$ & 0.035 & 0.003 \\
\hline currency $_{i t-1}$ & & 0.002 & -0.004 & expropri $_{i t-1}$ & $0.218 * * *$ & -0.029 \\
\hline corruption $_{i t-3}$ & -0.012 & & & currency $_{i t-1}$ & -0.003 & $-0.034 * *$ \\
\hline burean $_{i t-3}$ & 0.004 & & & checks $_{i t-1}$ & $0.035 *$ & \\
\hline$l a w_{i t-3}$ & 0.006 & & & priva $_{i t}$ & $0.185 *$ & $0.373 *$ \\
\hline expropri $i_{i t-3}$ & 0.011 & & & comp_fix_it & -0.216 & 0.026 \\
\hline currency $_{i t-3}$ & -0.004 & & & comp_cel_it & 0.001 & 0.072 \\
\hline checks $_{i t-1}$ & & $0.007^{*}$ & & rural $_{i t}$ & $0.108^{*}$ & $0.036 *$ \\
\hline checks $_{i t-2}$ & $0.003 * *$ & & & density $_{i t}$ & -0.001 & -0.008 \\
\hline checks $_{i t-3}$ & 0.001 & & & $m 1$ & $-2.00 * *$ & $-2.00 * *$ \\
\hline priva $_{i t}$ & $0.067 * *$ & $0.174 *$ & $0.249 * * *$ & $m 2$ & -0.81 & -0.88 \\
\hline comp_fix $x_{i t}$ & -0.004 & 0.033 & $-0.137 * *$ & $J$ & 5.12 & 5.86 \\
\hline comp_cel ${ }_{i t}$ & $0.021 *$ & $0.108 * *$ & 0.046 & Time dummy variables & $15.36 * *$ & $4.68 * * *$ \\
\hline rural $_{i t}$ & -0.002 & 0.007 & -0.003 & Endogenous reforms & No & Yes \\
\hline density $_{i t}$ & 0.001 & $-0.003 *$ & 0.005 & $L$ & 2 & 2 \\
\hline$m 1$ & $-3.20 * * *$ & $-2.74 * * *$ & $-3.06 * *$ & Number of observations & 150 & 162 \\
\hline$m 2$ & & 0.73 & & Goodness of fit & $116.81 * * *$ & $15.50 * * *$ \\
\hline$m 3$ & & & 1.32 & & & \\
\hline$m 5$ & 0.94 & & & & & \\
\hline$J$ & 1.33 & 3.91 & 7.62 & & & \\
\hline Time dummy variables & $3.01 * * *$ & $8.20 * * *$ & $2.11 *$ & & & \\
\hline
\end{tabular}

(Continued) 
TABle 4. Continued

\begin{tabular}{lccccc}
\hline $\mathrm{y}_{\mathrm{it}}$ & $\mathrm{ml}_{\mathrm{it}}$ & $\mathrm{cel}_{\text {it }}$ & eff $_{\text {it }}$ & $\mathrm{y}_{\mathrm{it}}$ & p_res $_{\text {it }}$ \\
\hline Endogenous reforms & Yes & No & Yes & \\
$L$ & 5 & 2 & 3 & \\
Number of observations & 295 & 318 & 316 & \\
Goodness of fit & $32.83^{* * *}$ & $130.40^{* * *}$ & $10.10^{* * *}$ & \\
\hline
\end{tabular}

"Significant at the 10 percent level; * significant at the 5 percent level; ** significant at the 1 percent level.

Note: For notational simplicity, the $\log$ and $\Delta$ transformations are implicit; $m n$ refers to the autocorrelation coefficient of order $n$ of the residuals in first differences found in the procedure used to search for (lag) instruments. The entry in the table corresponds to the value of its $t$-statistic. $J$ is the chi-square statistic used to test for the validity of the instruments. A high value indicates that the instruments are valid. Time dummy variables are a Wald (chi-square) statistic used to test the significance of time-specific effects. A yes or no for endogenous reforms indicates that the variables priva, comp_fix, comp_cel, and reg did or did not improve the overall goodness-of-fit statistic by being considered as endogenous and hence were or were not instrumented. $L(L-1)$ is the starting lag for the instruments used in the equation in first differences (levels).

Source: Authors' analysis based on data described in text and in Gasmi, Noumba, and Recuero Virto (2006). 
TABLE 5. Differenced generalized method-of-moments parameter estimates, developed countries

\begin{tabular}{|c|c|c|c|}
\hline $\mathrm{y}_{\mathrm{it}}$ & $\mathrm{ml}_{\mathrm{it}}$ & $\mathrm{cel}_{\mathrm{it}}$ & p_res $_{\text {it }}$ \\
\hline$y_{i t-1}$ & 0.039 & $0.503 * * *$ & -0.159 \\
\hline $\operatorname{reg}_{i t-2}$ & & $0.009 *$ & 0.006 \\
\hline corruption $_{i t-1}$ & & -0.043 & 0.038 \\
\hline bureau $_{i t-1}$ & & 0.012 & 0.073 \\
\hline $\operatorname{law}_{i t-1}$ & & 0.046 & 0.026 \\
\hline expropri $_{i t-1}$ & & 0.072 & 0.269 \\
\hline currency $_{i t-1}$ & & 0.007 & $-0.037 * *$ \\
\hline corruption $_{i t-2}$ & 0.007 & & \\
\hline burean $_{i t-2}$ & -0.005 & & \\
\hline $\operatorname{law}_{i t-2}$ & -0.006 & & \\
\hline expropri $i_{i t-2}$ & $-0.006^{*}$ & & \\
\hline currency $_{i t-2}$ & 0.001 & & \\
\hline checks $_{i t-1}$ & & $0.021 *$ & \\
\hline priva $_{i t}$ & $-0.014 *$ & 0.031 & 0.073 \\
\hline comp_fix $x_{i t}$ & 0.012 & $-0.082 * *$ & $0.109 *$ \\
\hline comp_cel ${ }_{i t}$ & -0.006 & -0.025 & -0.007 \\
\hline rural $_{i t}$ & 0.003 & 0.023 & -0.032 \\
\hline density $_{i t}$ & 0.001 & 0.008 & $0.020 * * *$ \\
\hline$m 1$ & $-2.87^{* * *}$ & $-3.52 * *$ & $-2.49 * *$ \\
\hline$m 2$ & 0.09 & & -0.87 \\
\hline$m 3$ & & 0.11 & \\
\hline$J$ & 4.41 & 0.00 & 3.55 \\
\hline Time dummy variables & $3.74 * * *$ & $3.57 * * *$ & $75.60 * * *$ \\
\hline Endogenous reforms & Yes & Yes & No \\
\hline$L$ & 2 & 3 & 2 \\
\hline Number of observations & 276 & 275 & 182 \\
\hline Goodness of fit & $62.31 * * *$ & $53.35 * *$ & $11,625.52 * * *$ \\
\hline
\end{tabular}

*Significant at the 10 percent level; **significant at the 5 percent level; ***significant at the 1 percent level.

Note: For notational simplicity, the $\log$ and $\Delta$ transformations are implicit. $m n$ refers to the autocorrelation coefficient of order $n$ of the residuals in first differences found in the procedure used to search for (lag) instruments. The entry in the table corresponds to the value of its $t$-statistic. $J$ is the chi-square statistic used to test for the validity of the instruments. A high value indicates that the instruments are valid. Time dummy variables are a Wald (chi-square) statistic used to test the significance of time-specific effects. A yes or no for endogenous reforms indicates that the variables priva, comp_fix, comp_cel, and reg did or did not improve the overall goodness-of-fit statistic by being considered as endogenous and hence were or were not instrumented. $L(L-1)$ is the starting lag for the instruments used in the equation in first differences (levels).

Source: Authors' analysis based on data described in text and in Gasmi, Noumba, and Recuero Virto (2006).

performance as reflected in higher output (increase in mainline coverage and cellular subscription), higher efficiency (increase in mainlines per employee), and lower prices (decrease in price of cellular service).

The apparently counterintuitive case, where greater political accountability (less risk of expropriation for operators and stronger checks and balances) 
TABle 6. Impact of Political Accountability on Regulatory Performance in Developing and Developed Countries

\begin{tabular}{|c|c|c|c|c|c|c|}
\hline \multirow[b]{3}{*}{ Variable } & \multirow{2}{*}{\multicolumn{2}{|c|}{$\begin{array}{c}\text { Local accountability } \\
\text { reg }\end{array}$}} & \multicolumn{4}{|c|}{ Global accountability } \\
\hline & & & \multicolumn{2}{|c|}{ institutional } & \multicolumn{2}{|c|}{ checks } \\
\hline & $\begin{array}{c}\text { Developing } \\
\text { countries }\end{array}$ & $\begin{array}{l}\text { Developed } \\
\text { countries }\end{array}$ & $\begin{array}{c}\text { Developing } \\
\text { countries }\end{array}$ & $\begin{array}{l}\text { Developed } \\
\text { countries }\end{array}$ & $\begin{array}{c}\text { Developing } \\
\text { countries }\end{array}$ & $\begin{array}{c}\text { Developed } \\
\text { countries }\end{array}$ \\
\hline$m l$ & + & NA & NS & - & + & NA \\
\hline cel & NA & + & + & NA & + & + \\
\hline eff & NA & NA & + & NA & NA & NA \\
\hline p_res & - & NA & + & - & + & NA \\
\hline p_cel & - & NA & - & NA & NA & NA \\
\hline
\end{tabular}

NA is not applicable; NS indicates that no significant effect was found; + indicates a positive and significant effect; - indicates a negative and significant effect.

Source: Authors' analysis based on data described in text and in Gasmi, Noumba, and Recuero Virto (2006).

leads to a higher price of monthly subscription to fixed-line service, might in fact only reflect the extent of tariff rebalancing that typically takes place in developing countries during the early stages of reform. When local accountability (regulatory governance) is distinguished from global accountability, global accountability is more often found to have a significant impact on regulatory performance. Nevertheless, in the cases when regulatory governance is found to be significant, its effect on regulatory performance has the expected sign.

The results for the developed country data sets do not convey the same messages, with results that are generally poor compared with those for developing countries (see table 5). Indeed, the only expected results were found when using mainline coverage, cellular subscription, or price of monthly subscription to fixed-line service to measure regulatory performance. For the impact of political accountability on regulatory performance, the only expected result was a positive effect of regulatory governance and checks and balances on cellular subscription and the price of monthly subscription to fixed-line service, which decreases when the currency risk to operators diminishes.

The dummy variables used to capture time-specific effects are highly significant, suggesting that attention should be given to important political and economic events in a country when examining the performance of regulation. The reform variables were found to be endogenous in all the regressions except when regulatory performance was measured by cellular subscription and by the price of monthly subscription to fixed-line sevice in the developing country regressions and by the price of monthly subscription to fixed-line service in developed country regressions. These results are consistent with the idea that reforms are increasingly performance based.

Overall, then, there are reasons to believe that local accountability (here synonymous with regulatory governance) generally affects regulatory 
performance in a significant way in developing as well as developed countries. The story is not so clear for global accountability. For developing countries, the quality of the political process and the institutional environment have a favorable impact on regulatory performance in the telecommunications industry when performance is evaluated by the level of output, price, or efficiency. For developed countries, however, while the quality of the political process has a positive impact on regulatory performance when performance is measured by output, the impact was ambiguous when regulatory performance is measured by output and prices.

Table 6 summarizes the findings. The variable institutional, an index reflecting the quality of the institutional environment, is constructed by aggregating five indices on the extent of corruption in the country (corruption), the burden of the bureaucracy (bureau), the strength of the judicial system and the degree of observance of the law (law), the risk of expropriation through asset confiscation or nationalization (expropri), and the risk of losses to operators due to exchange rate fluctuations (currency). The effect of this aggregate index is consistent with the effects of the individual indices that compose it (shown in tables 4 and 5).

\section{CONCLUSION}

Two data sets, one on developing countries and one on developed countries, were used to estimate the impact of political accountability variables on outcome variables measuring regulatory performance. The empirical analysis showed a relatively weak effect of political accountability on the performance of regulation in developed countries and a much more clear-cut effect in developing countries, where greater political accountability yields higher regulatory performance.

What implications can be derived from these findings for the telecommunications industry and, to some extent, for other infrastructure industries? ${ }^{13}$

During the last two decades, many developing countries have created regulatory agencies mostly on the model recommended by international financial institutions and international lawyers. However, these new regulatory institutions were not adequately adapted to local cultural, political, and social endowments. This article again stresses this as an important requirement for success in developing new institutions. Furthermore, the article goes beyond most recent analyses by extending the focus to issues of global (economywide) accountability, which reflect the quality of political institutions.

13. Although the results found for the telecommunications industry might be expected to hold for other infrastructure industries in their general spirit, this study calls for a careful examination of alternative sectors such as energy or water that, among other things, accounts for the industry technological specificities. 
Recent contributions to the literature have deepened understanding of regulatory effectiveness along two dimensions: regulatory governance, a concept that is somewhat broader than encompassed by the concept of local accountability here, and regulatory substance, a concept that captures how regulation is actually implemented. Brown and others (2006) have proposed a comprehensive process for evaluating the effectiveness of regulatory institutions that highlights not only structural weaknesses but also deficiencies stemming from the surrounding environment of regulation, particularly the political environment.

Thus, it is important to devise policy mitigation instruments that incorporate both of these dimensions. Instead, donor interventions over the last decade or so have centered on structural issues. The empirical analysis reported in this article strongly supports defining a set of instruments of effective intervention, with the objective of improving political accountability in the implementation of regulation. Building sound regulatory institutions in developing countries should be viewed as part of a broader strategy of good governance rather than merely as a sectoral matter, as has been the case.

Building regulatory institutions in developing countries has proven to be more complex than expected. The analysis here shows that regulatory governance is a necessary condition for regulatory performance but it is not sufficient to ensure good performance. Political accountability matters for the way regulatory institutions operate and make decisions. Deepening the understanding of these relationships calls for a better assessment of the political economy of infrastructure reforms as well as better analysis and understanding of how political systems work, and that calls for greater integration of the work of economists and political scientists in the design of regulatory institutions. Finally, building new institutions requires time. Regulatory institutions in developing countries need support. For development partners, this means a greater concentration on countries where preconditions for success are relatively tangible.

\section{SuPPlEMENTARY MATERIAL}

Supplemental appendix to this article is available at http://wber.oxfordjournals. org/.

\section{FUNDING}

We gratefully acknowledge the financial support of the Public-Private Partnerships in Infrastructure Program of the World Bank Institute. 
Appendix: Data Summary Statistics for Developing and Developed Countries

\begin{tabular}{|c|c|c|c|c|c|c|c|c|c|c|c|}
\hline \multirow[b]{2}{*}{ Variable } & \multirow[b]{2}{*}{ Designation } & \multicolumn{2}{|c|}{ Number of observations } & \multicolumn{2}{|c|}{ Median } & \multicolumn{2}{|c|}{ Standard deviation } & \multicolumn{2}{|c|}{ Minimum } & \multicolumn{2}{|c|}{ Maximum } \\
\hline & & $\begin{array}{c}\text { Developing } \\
\text { countries }\end{array}$ & $\begin{array}{l}\text { Developed } \\
\text { countries }\end{array}$ & $\begin{array}{c}\text { Developing } \\
\text { countries }\end{array}$ & $\begin{array}{c}\text { Developed } \\
\text { countries }\end{array}$ & $\begin{array}{l}\text { Developing } \\
\text { countries }\end{array}$ & $\begin{array}{c}\text { Developed } \\
\text { countries }\end{array}$ & $\begin{array}{l}\text { Developing } \\
\text { countries }\end{array}$ & $\begin{array}{c}\text { Developed } \\
\text { countries }\end{array}$ & $\begin{array}{c}\text { Developing } \\
\text { countries }\end{array}$ & $\begin{array}{l}\text { Developec } \\
\text { countries }\end{array}$ \\
\hline \multicolumn{12}{|c|}{ Regulatory performance } \\
\hline$m l$ & Mainline coverage & 435 & 345 & 3.76 & 47.49 & 4.96 & 10.87 & 0.11 & 14.52 & 22.36 & 73.56 \\
\hline $\mathrm{cel}$ & Cellular subscription & 431 & 344 & 0.01 & 2.55 & 2.09 & 13.51 & 0.00 & 0.00 & 15.96 & 63.37 \\
\hline eff & Mainlines per employee & 424 & 345 & 53.06 & 166.08 & 58.85 & 57.53 & 7.78 & 43.48 & 371.16 & 358.76 \\
\hline p_res & $\begin{array}{l}\text { Price of monthly subscription } \\
\text { to fixed-line service }\end{array}$ & 256 & 252 & 4.44 & 4.70 & 4.23 & 4.70 & 0.00 & 5.60 & 21.29 & 26.27 \\
\hline \multicolumn{8}{|c|}{ Local accountability } & 0.00 & 0.00 & 2.24 & 4.95 \\
\hline $\begin{array}{l}\text { reg } \\
\text { Global accou }\end{array}$ & $\begin{array}{l}\text { Regulatory governance index } \\
\text { untability }\end{array}$ & 435 & 345 & 0.00 & 0 & 4.60 & 3.11 & 0.00 & 0.00 & 13.50 & 8.00 \\
\hline corruption & Corruption & 435 & 345 & 5.00 & 8.33 & 1.43 & 1.37 & 1.66 & 3.33 & 10.00 & 10.00 \\
\hline bureau & Bureaucracy & 420 & 345 & 5.00 & 10.00 & 1.86 & 1.33 & 1.66 & 4.50 & 10.00 & 10.00 \\
\hline law & Law and order & 435 & 345 & 5.00 & 10.00 & 2.06 & 1.11 & 0.00 & 5.00 & 10.00 & 10.00 \\
\hline expropri & Expropriation & 420 & 345 & 7.35 & 10.00 & 2.00 & 0.66 & 2.00 & 4.60 & 10.00 & 10.00 \\
\hline currency & Currency risk & 435 & 345 & 6.00 & 9.00 & 1.98 & 1.16 & 1.00 & 4.00 & 10.00 & 10.00 \\
\hline institutional & $\begin{array}{l}\text { Institutional environment } \\
\text { index }\end{array}$ & 435 & 345 & 28.66 & 47.00 & 7.10 & 3.99 & 8.00 & 25.26 & 41.16 & 50.00 \\
\hline checks & Checks and balances & 423 & 345 & 3.00 & 4.00 & 2.06 & 1.62 & 1.00 & 2.00 & 18.00 & 16.00 \\
\hline \multicolumn{12}{|c|}{ Other variables } \\
\hline priva & Privatization & 435 & 345 & 0.00 & 0.00 & 0.32 & 0.48 & 0.00 & 0.00 & 1.00 & 1.00 \\
\hline comp_fix & Competition in fixed & 435 & 345 & 0.00 & 0.00 & 0.29 & 0.42 & 0.00 & 0.00 & 1.00 & 1.00 \\
\hline comp_cell & Competition in cellular & 435 & 345 & 1.00 & 0.00 & 1.10 & 0.47 & 0.00 & 0.00 & 3.00 & 1.00 \\
\hline rural & Rural population & 435 & 345 & 49.82 & 24.70 & 20.95 & 12.73 & 10.95 & 2.95 & 90.31 & 62.84 \\
\hline density & Population density & 435 & 345 & 48.07 & 94.59 & 79.39 & 119.50 & 5.38 & 2.01 & 330.34 & 466.49 \\
\hline
\end{tabular}

Source: Authors' analysis based on data described in text and in Gasmi, Noumba, and Recuero Virto (2006). 


\section{REFERENCES}

Ackerman, J.M. 2005. "Social Accountability in the Public Sector: A Conceptual Discussion." Social Development Paper 82. World Bank, Washington, D.C.

Arellano, M., and S.R. Bond. 1991. "Some Tests of Specification for Panel Data: Monte Carlo Evidence and an Application to Employment Equations." Review of Economic Studies 58(2):277-97.

Arellano, M., and O. Bover. 1995. "Another Look at the Instrumental Variable Estimation of Error-Component Models." Journal of Econometrics 68(1):29-51.

Beck, N., and J. Katz. 2004. "Time-Series-Cross-Section Issues: Dynamics." Paper presented at the 2004 Annual Meeting of the Society for Political Methodology. Stanford University, Palo Alto, Calif., July $29-31$.

Blundell, R., and S. Bond. 1998. "Initial Conditions and Moment Restrictions in Dynamic Panel Data Models." Journal of Econometrics 87(1):115-43.

1999. GMM Estimation with Persistent Panel Data: An Application to Production Functions. Institute for Fiscal Studies Working Paper Series W99/4. London: Institute for Fiscal Studies.

Brown, A.C., J. Stern, B. Tenenbaum, and D. Gencer. 2006. Handbook for Evaluating Infrastructure Regulatory Systems. Washington, D.C.: World Bank.

Correa, P., M. Melo, B. Mueller, and C. Pereira. 2008. "Regulatory Governance in Brazilian Infrastructure Industry." The Quarterly Review of Economics and Finance 48(2):202-16.

Cubbin, J., and J. Stern. 2005a. "Regulatory Effectiveness and the Empirical Impact of Variations in Regulatory Governance: Electricity Industry Capacity and Efficiency in Developing Countries.” Policy Research Working Paper 3535. World Bank, Washington, D.C.

- 2005b. "Regulatory Effectiveness: The Impact of Regulation and Regulatory Governance Arrangements on Electricity Industry Outcomes." Policy Research Working Paper 3536. World Bank, Washington, D.C.

Estache, A., and D. Martimort. 1999. "Politics, Transactions Costs, and the Design of Regulatory Institutions." Policy Research Working Paper 2073. World Bank, Washington, D.C.

Gasmi, F., P. Noumba, and L. Recuero Virto. 2006. "Political Accountability and Regulatory Performance in Infrastructure Industries: An Empirical Analysis.” Policy Research Working Paper 4101. World Bank, Washington, D.C.

Gasmi, F., and L. Recuero Virto. Forthcoming. "The Determinants of Reforms and Their Impact on Telecommunications Deployment in Developing Countries.” Journal of Development Economics.

Gutierrez, L. H. 2003a. "The Effect of Endogenous Regulation on Telecommunications Expansion and Efficiency in Latin America.” Journal of Regulatory Economics 23(3):257-86.

- 2003b. "Regulatory Governance in the Latin American Telecommunications Sector." Utilities Policies 11(4):225-40.

Heller, W.B., and M.D. McCubbins. 1996. "Politics, Institutions, and Outcomes: Electricity Regulation in Argentina and Chile." Journal of Policy Reform 1(4):357-87.

Holder, S., and J. Stern. 1999. "Regulatory Governance: Criteria for Assessing the Performance of Regulatory Systems." Utilities Policies 8(1):35-50.

Holtz-Eakin, D., W. Newey, and H.S. Rosen. 1988. "Estimating Vector Autoregressions with Panel Data." Econometrica 56(6):1371-95.

Laffont, J.J. 2005. Regulation and Development. Cambridge: Cambridge University Press.

Levy, B., and P.T. Spiller. 1994. "The Institutional Foundations of Regulatory Commitment: A Comparative Analysis of Telecommunications Regulation." Journal of Law, Economics and Organization 10(2):201-46.

McCubbins, M.D., R.G. Noll, and B.R. Weingast. 1987. "Administrative Procedures as Instruments of Political Control." Journal of Law, Economics and Organization 3(2):243-77.

McCubbins, M.D., and T. Schwartz. 1984. "Congressional Oversight Overlooked: Police Patrol vs Fire Alarms.” American Journal of Political Science 28(2):165-79. 
North, D.C. 2000. "Institutions and the Performance of Economies over Time." Paper presented at the Second Annual Global Development Conference, Tokyo December 10-13.

Rodrik, D., A. Subramanian, and F. Trebbi. 2004. "Institution Rule: The Primacy of Institutions Over Geography and Integration in Economic Development." Journal of Economic Growth 9(2):131-65.

Ros, A.J. 1999. "Does Ownership and Competition Matter?: The Effects of Telecommunications Reform on Network Expansion and Efficiency." Journal of Regulatory Economics 15(1):65-92.

- 2003. "The Impact of the Regulatory Process and Price Cap Regulation in Latin American Telecommunications Markets." Review of Network Economics 2:270-86.

Spiller, P.T., and M. Tommasi. 2003. "The Institutions of Regulation: An Application to Public Utilities.” In S. Majumdar, I. Vogelsang, and M. Cave eds., Handbook of Telecommunications Economics: Technology Evolution and the Internet, Vol. 2., Amsterdam: North-Holland. 